\title{
LIVING MEMORY IN P.I. ZINCHENKO'S RESEARCH (A RETROSPECT AND A PROSPECT) ${ }^{1}$
}

\author{
V.P. ZINCHENKO
}

Everything can be made natural. Blaise Pascal

\section{Fate and chance}

The sentence, apparently over-optimistic, "Manuscripts do not burn" belongs to Mikhail Bulgakov, which is relevant not only to literature but also to science. Different types of memory are inherent to both science and man: short-term, operative memory, longterm and permanent, or autobiographical (history). Some aspects of longterm memory suddenly become relevant and re-enter the scientific discourse. The works of my father Pyotr Zinchenko that he conducted in the 1930-60s owe to such a "suddenly" that was the efforts of B.G. Meshcheryakov who not only thought of them but also took the trouble to compare them with works of our Englishspeaking colleagues. I am very pleased that they did not remain indifferent either to the article by B.G. Meshcheryakov, or to the work by P.I. Zinchenko. And it certainly is not the establishment of priority in stating an idea or in discovering an effect or phenomenon that counts here. The question of priority in science is rather sensitive and secondary. Sometimes it is not the person who first suggests an idea who is more important, but the one who first rejects it. It is, above all, the dialogue and resonance of ideas, conceptual schemes and theories, as well as the mutual amplification of scientific concepts that are of significance. And the dialogue, which happened so late, is, in my opinion, certainly productive. It opens up new prospects for memory research.

My father died in 1969, before the first publications by Craik and Lockhart, Mace and MacCafferty, when he was about 66 years old (which was not too little for someone who had fought in the Second World War). In my 78 years he remains alive in my memory.

I am sincerely grateful to all the authors who participated in the discussions, for the appreciation of P.I. Zinchenko's memory research. I suspect that both the interpretation of memory

${ }^{1}$ Translated from: Zinchenko, V. P. (2009). Living Memory in P.I. Zinchenko Research (Retrospective and Prospective). Cultural-Historical Psychology, 3, 2-15. Translated and published with a permission of the publishing house «Tsentr gumanitarnykh initsiativ». 
(especially involuntary rather than incidental) and the concepts developed by participants in the discussion are equally aimed at clarifying Spinoza's wise thesis that although the memory itself was born out of an idea, it is an intellect searching for itself. Memory not only does find but also keeps and puts it together. According to M. Heidegger, memory is a concentration of thought. This characteristic of memory corresponds to the statement by L. Vygotsky on intellectualization of higher mental functions (this is again relevant to the question of priority). P.I. Zinchenko found intelligence in involuntary memory, which is not only increased but is also constructed by such mental activities as classification. So he tried to reorient the educational activity of pupils and students from learning the material to its understanding and interpretation. This point happened to be missed by his (and my) friends D.B. Elkonin and V.V. Davydov when they were creating their version of the theory of learning activity.

Before joining in the discussion, I would like to add some finishing touches to the biography of my father. Here I will not be able to resist "reconstructions when reproducing" that were so well described and justified by F. Bartlett in his book on memory published in 1932. Reconstructing while reproducing is typical when recalling one's own fate and life. It is also permissible when reproducing my own father's life, which wasn't unfamiliar to me, as he is constantly present in my involuntary memory. He still plays the role of the affective-cognitive and behavioural image of conscience in my life.

I would like to dedicate the first (and most important!) story to Fate and Chance. I think that studying memory was his fate, or, as they say in Russia, "he was destined to do that." However, fate too often happens to be impotent without chance and without the "I want and I can," i.e. without feelings and the will. Nevertheless, "Chance is the logic of Fortune" (according Vladimir Nabokov).

So, P.I. Zinchenko was born in 1903 in a large peasant family in the village of Nikolayevskaya on the Lower Volga River. There were 13 children in the family (only six of them lived into old age), and he alone graduated from a university. Initially he graduated from the Pedagogical Seminary, and on having a short teaching practice he became a school inspector. We can assume that in his work first as a teacher and then as an inspector he became interested in school students' memory that (at least from the point of view of teachers) is never sufficient when mastering the necessary (is it always necessary?) study material. There is an old maxim by La Rochefoucauld that is still relevant: "Everyone complains about their memory, and no one complains of their mind." Perhaps P.I. Zinchenko was struck (like I was later) by the contrast between the weakness of arbitrary memory of students and the surprisingly robust penetrating mind and great living memory of his illiterate mother - my grandmother Tatiana Petrovna, who had lived till 90 years of age and who died in the same year as he did. Perhaps he did not just take interest in studying memory but he was caught up in its mystery. And, judging by his later life, the solving of the mystery became his fate.

One way or another but my father decided to continue his education and 
become a psychologist. In the second half of the 1920s he tried to enter the Faculty of Psychology (Pedology at that time) of the Second Moscow University where P.P. Blonsky, L.S. Vygotsky, G.G. Shpet, A.R. Luria and probably A.N. Leontiev as well as many other eminent psychologists taught. However, this teacher from the Lower Volga was not accepted. If he had succeeded in his attempt, he would have studied with his future friends and colleagues who later became well-known disciples of L.S. Vygotsky (V.I. Asnin, L.I. Bozovic, A.V. Zaporozhets, R.E. Levina, N.G. Morozova and L.S. Slavina). P.I. Zinchenko returned home and was soon conscripted into the army. By chance he was sent to serve in one of the most cultural cities of Russia Kharkov, the then capital of Ukraine. Having served in the army he did not return home but he entered the Kharkov Pedagogical University (then known as the Institute of Socialist Education), from which he graduated in 1930. In the same year A.V. Zaporozhets and others graduated from the university in Moscow. And there fate came into its own. In the early 1930s Vygotsky's colleagues and students "caught up" with him in Kharkov, and Vygotsky himself came to Kharkov a few times to promote the development of the Kharkov School of Psychologists (see more about it: Cole, 1980; Valsiner, 1988; Yasnitsky \& Ferrari, 2008b). And it is not by chance that P.I. Zinchenko chose his peer A.N. Leontiev to be his scientific supervisor, the latter having already published the book The Development of Memory in 1931. P.I. Zinchenko maintained a sustainable interest in memory, and his first thesis was on the memory of schoolchildren, though not on remembering but on forgetting the knowledge gained at school. The general motive and the result of this work was that forgetting the form in which school knowledge is presented is no tragedy. Both the essence and the meaning of the knowledge gained stay intact. It is noteworthy that already in this work he was considering the process of forgetting not as passive immersion of memory contents into some conceivable "physical base," but as an action of their semantic (semiotic) re-encoding, or transformation. Thus, forgetting helps institutionalized knowledge become part of the living knowledge, for example, similar to a good teacher's. It is unlikely that P.I. Zinchenko knew about the book by F. Bartlett at the time. History repeats itself. A reference to it only appeared in his book in the year 1961 (Zinchenko P., 1961). Unfortunately, forgetting rarely becomes a subject of psychological research. There is even less focus on the idea that without forgetting and reconstruction when reproducing there would not be a full memory, but only a literal memory, such as A.R. Luria described in A Little Book of a Vast Memory (Luria, 1968). The main character Sh. has an absolute memory but is unable to create and cannot "turn a swarm into a system." G.G. Shpet wrote that forgetting is a whip of creativity, it makes fantasy prance (Shpet, 1989, p. 360). However, fantasy must also have its limits: A matter of memory becoming into a matter of imagination is a descent (Hegel). Apparently, the results obtained in the study of forgetting prompted P.I. Zinchenko to suggest that repetition and memorization is not the only or most effective way of 
acquiring knowledge. And he turned to studying living involuntary memory.

Thus, fate and chance made P.I. Zinchenko a full member of the Kharkov Psychological School and bound him to his friends and colleagues for life (except for the dashing years of World War II where he happened to be a sapper), some of whom later moved to Moscow. The departure to Moscow of A.N. Leontiev, A.R. Luria, A.V. Zaporozhets, and P.Ya. Galperin forced him to become an informal leader of the Kharkov School from 1945. He performed this role in good faith, responsibly, but without joy. He got much greater joy from his pedagogical work with students and graduate students and his experimental studies of memory.

P.I. Zinchenko had a huge, almost improbable, though quite unintentional influence on the fate of his loved ones. His wife, my mother, Vera Davidovna, studied with him; she became a teacher and then began teaching psychology at the Kharkov Conservatory. My sister - Tatiana Zinchenko (19392001) - and I became psychologists. (My father tried to persuade me to relinquish the idea of becoming a psychologist, he spoke ironically about psychology saying that it was no profession but a rather narrow specialty and that psychology compared to theology and medicine was the most accurate science, etc...). My wife Natalia Gordeyeva graduated from biology but became a psychologist. Our son Alexander also became a psychologist and married a psychologist, Alla Volovich. Now they both work as psychotherapists and live in Berkeley.

Perhaps the most surprising thing is that both their son and daughter followed him and devoted a lot of time to studying memory. And the grandson, once in the United States, defended a doctoral dissertation on nostalgia, which is the brightest form of permanent memory (albeit involuntary but indestructible), perhaps, a genetic memory. This is the sort of involuntary memory that is stronger than any arbitrary memory. But some doubt the existence of a cultural genetic memory. The history of our family is the evidence that such doubts are unfounded.

If the impossible happened and the whole family got together, we being led by P.I. Zinchenko could open, I hope, a good College of Psychology.

\section{Cultural and historical context}

I shall address early research and publications by P.I. Zinchenko where forgetting and remembering are interpreted as special mnemonic (in the broadest sense) mental actions or as the result of cognitive, mental and practical actions. Both of his studies were published in a low-circulation edition that was hardly known to psychologists (except for his colleagues in Kharkov) - in The Scientific Notes of the Kharkov Pedagogical Institute of Foreign Languages. Regardless of how to interpret the criticism of Vygotsky in P.I. Zinchenko's article about remembering (I agree with the interpretation proposed by B.G. Meshcheryakov (2004)), his own research, as set out in it, is quite consistent with the spirit of the cultural-historical theory of Vygotsky. Memory was considered in the research not as a natural mental function but as a cultural function mediated by action. Zinchenko began to consider action as a mediator, which (along with a sign, a word and a sym- 
bol) plays a crucial role in forming memory as a higher mental function. The research novel aspect (in comparison with the cultural-historical approach to psyche and consciousness) was that the very mnemonic action became the subject and object of a psychological research. His way of studying memory was so original as he did not learn the mnemonic action, so to speak, "head-on," but approached it gradually: from the study of indicative, cognitive, mental actions, that is, from actions ensuring the effectiveness of involuntary memory. He then traced how these targeted actions (that were independent before) in turn transform into methods, techniques, and operations of targeted mnemonic action. Thus, in the studies by P.I. Zinchenko action was a unit of structural, functional and genetic memory analysis.

It should be recalled that while P.I. Zinchenko was working alongside other great researchers: A.V. Zaporozhets studied sensory and intellectual action; V.I. Asnin's work was focused on action per se, i.e. on practical action (skills); P.Ya. Galperin studied instrumental action. All of these studies of the 1930s developed Vygotsky's ideas and at the same time served as a foundation for the psychological theory of activity later established by A.N. Leontiev. It would be naive to think that a certain theory of activity had preceded these studies. Rather, we can speak of sensing the theory that is easily found in the works of L.S. Vygotsky himself and in the book by A.R. Luria The Nature of Human Conflicts (Luria, 2002). For example, P.I. Zinchenko wrote that Vygotsky planned to approach memory as an activity with special functions: “...memory means the use and involvement of previous experience in current behaviour; from this point of view memory is an activity in the strict sense of the word, both at the time of reinforcing the reaction and at the time of reproducing it" (Vygotsky, 1926, p. 153). It is not important who used the concept of activity in the context of the psychology of memory but it matters what development was given to the idea of interpreting psyche as a mental activity. Ironically, the development was facilitated by the fact that in the early 1930s A.N. Leontiev refused to use Vygotsky's program aimed at the study of consciousness (which was dangerous at that time), and began to plan his own program of psychological research. It gradually acquired the outlines of a program for activity research that was not in the least due to his increased sensitivity to the methodological imperative (according to P. Feyerabend) of the dominant Marxist ideology. Only in 1967 Leontiev fully appreciated the significance of $\mathrm{Vy}$ gotsky's contribution to the study of consciousness. A few years later he proposed a productive way to study consciousness by highlighting meaning, sense and sensual tissue as its constituents.

Looking back, we can state not without regret that Leontiev presented his version of the psychological theory of activity in a rather abstract form, with an emphasis on its philosophical and sociological justifications. Rich empiricism and experimental studies obtained by his colleagues did not serve as a foundation of his theory. In those he saw only his abstractions illustrated and filtered out the rest as irrelevant to the theory. This contributed to the gradual transformation of the concept 
of activity into methodological (in the philosophical sense of the word) principle of explaining all human mental life, including consciousness and personality. Today, these claims have decreased significantly, but the momentum has been maintained. In fact, there was a certain logic in what happened to the psychological theory of action. Any concept (be it a concept of activity, of consciousness, of mindset, of Gestalt and so on) used as a means of explaining another reality (including that of psyche), as Marx wrote, is subjected to evaporation by transforming it into abstract definitions. Such definitions are necessary, for on their basis it is possible to reproduce the specific. However, there is a blessing in disguise. Studying the development of various mental activities and later their structure became such a specific. And the principle of activity performed then a useful protective function by protecting ideologically careless scientists who worked within its framework (or under the shelter!?). These scientists, including, of course, A.N. Leontiev, studied instrumental, sensory, perceptual, mnemonic and intellectual actions that have an independent scientific value, regardless of any theory of activity. The research of these actions completed in the 1930s and in the following years represents a kind of prolegomena to a future and long-overdue general psychological theory of action. In the study of action it is impossible to oppose as drastically (as in the theory of activity) the external and internal, executive and mental, cognitive acts, which prevents the study of both and transforms empirically observable effects of internalization and externalization in the scientific and philosophi- cal paradigm, but in fact come to a dead end with no escape. In order to come up with the idea of internalization, there is no need to be a scholar of psychology, whether his name is P. Janet and L.S. Vygotsky. In 1922, V. Meyerhold wrote: "The main drawback of the modern actor is an absolute ignorance of modern biomechanics. Only a few outstanding actors intuitively guessed the correct method of play, that is the principle of approaching a role not from internal to external, but rather from the outside to the inside, which certainly contributed to the development of their enormous technical skill; such were Duse, Sarah Bernhardt, Grasso, Chaliapin, Coquelin, and others..." (Meyerhold, 1968, Vol. 2, pp. 488-489).

It is short-sighted and ill-advised to spread this position for all work in the arts, and even more so to the whole psychology. V. Kandinsky argued that "the external that was not born by the internal, is stillborn" (Kandinsky, 2004, p. 28).

Indeed, the individual's psychology is integrated in its totality in action; perceptual, mnemonic, mental, practical actions, affects and emotions are conditional concepts only acceptable in terms of analytical abstraction, for the listed attributes are inseparable from each other in live action and even in living motion. S.L. Rubinstein saw the beginnings of all the elements of psychology in action that gave grounds to his assertion that action is the original unit of analysis of the entire psyche. However, action, as well as activity, is not so much internalized as it is differentiated. I think it is no coincidence that in P.I. Zinchenko's thesaurus there was no place for the concept of internalization. It should also be noted that 
the tasks of deducing mental acts from action and reducing them to it are not symmetrical. Therefore the analytical abstraction of mental acts and their study are quite legitimate, likewise is their interpretation in terms of cognitive action. With regard to the concept of activity, today it has largely lost its role of a universal explanatory principle, but, in comparison with action, it has not yet become a full-fledged subject of scientific research. What was supposed to happen did happen. The studied components of the structure of activity proposed by A.N. Leontiev grew much richer than the context they belonged to, and this caused the need to create a psychological theory of action. The ideas of individual (or special, in the terminology of A.N. Leontiev) activities (of communication, of playing, of learning and of labour) appeared to be richer too. By the mid1970 s it was recognized by A.N. Leontiev as well: "Human activity does not exist other than in the form of action or a chain of actions $<\ldots>$ dependent on particular purposes that can stand out from the common purpose $<\ldots>$ the role of the common purpose is performed by a deliberate motive that turns, thanks to its awareness, into the motive - purpose" (Leontiev, 1983, Vol. 2, pp. 154-155). Thus, the author's previously set qualitative difference between activity and action is erased: activity is subordinate to the motive, action is subordinate to the purpose. Only the quantitative remains. E.G. Yudin (1978) was right claiming that the essence of the activity approach to psychology was the study of action.

Hence the importance of appealing to the origins of a possible general psy- chological theory of action. This probably explains the interest in the initial stage of establishing the Kharkov Psychological School (Yasnitsky, 2008; Yasnitsky \& Ferrari, 2008a). There is another, seemingly outward, but not less important, good reason to refer to the first works of the scientists as the former contain a special flavour of direct and sincere surprise at what was revealed in the mysterious act of intuition. The works yet have no academic patina. There is joy of intuition prevailing over the burden of proof required. The above is certainly of general nature and applies not only to the representatives of the scientific school under discussion. I am far from doubting the existence of the theory of activity. There are enough doubters enough without me, and perhaps its schematic form is to blame. S.L. Rubinstein in his later years relinquished his focus on the subject-object paradigm and addressed the problem of Man-World (1973). A.N. Leontiev in his last works (1983) also concentrated on the Image of the World. It seems to me that such a reorientation should give new impetus to the development of the theory of activity. A.N. Leontiev regarded the concept of activity as synonymous to subject activity, the latter being well within the subject-object paradigm. By the way, the cultural-historical psychology does not fit into the paradigm. A paradigm shift and an appeal to the World urgently require addressing the analysis of spiritual activity. Of ultimate value there for psychology are the lessons of M. Heidegger, M. Bakhtin, V.V. Bibikhin, M.K. Mamardashvili, and G.G. Shpet. New aspects may be seen in the study of living memory by P.I. Zinchenko, of living motion by 
N.A. Bernstein, of arbitrary (free) action by A.V. Zaporozhets, as well as approaches to the study of consciousness by L.S. Vygotsky, S.L. Rubinstein and A.N. Leontiev, and the development of these approaches in the work of F.Ye. Vasilyuk and V.P. Zinchenko.

After expressing the general considerations let me join in the discussion. I have no intention of writing a comment to the comments for which I can only once again express my gratitude to all the authors. I will dwell on two issues that I think are most important. The first is the tiered structure of the memory being wider than both psyche and consciousness. The second is the ratio of the direct and indirect in human behaviour and activity.

\section{Depth of processing and activity levels}

Too much in psychology remains unexplained beyond the idea of development (of disontogenesis and decay). In any study there are steps, stages and levels distinguished. Problems of the structural characteristics of a particular level occur as well as those referring to the structure of the existing mental act as a whole. One of the first ideas of the structure of consciousness belongs to Freud. He applied a topographic approach to psyche phenomena and singled out the conscious, preconscious, and unconscious and identified them as dynamic systems with their own functions, procedural characteristics, energy and ideational content. Despite the diverse, sometimes well-founded criticism, Freud's ideas of the tiered structure of consciousness became a clichй or a schema not only of psychological consciousness, but of the consciousness of
European culture of the $\mathrm{XX}$ century. This is still relevant in the XXI century.

In 1922 G. Shpet proposed the concept of separating levels of perception and understanding of the words (and that was of direct relevance to the issue of consciousness tiers): on hearing a word $N$ pronounced we are able to distinguish the sound perceived (1) as the voice of a person from other natural sounds, to perceive it as a general sign of man; (2) as the voice of $N$ from the voices of other people as an individual sign of $N$; (3) as a sign of special psycho-physical (natural) state of $N$, unlike other possible states of his or of any another person. All these functions are natural. Next, we take the word as not only a phenomenon of nature, but also as a fact and "thing" of the cultural and social world. We take the word as (4) as a sign of the culture present and of $N$ belonging to a less or more conscious circle of human culture and human society bound by the unity of language. If it turns out that the language is familiar to us, then we (5) recognize it as a particular language, we learn its phonetic, lexical and semasiological features, and (6) at the same time we understand the word heard, that is we grasp its meaning while at the same time distinguishing the reported content by its quality of being a simple message, an order, a question and so on, i.e. we insert the word in some semantic and logic nominative context known to us and understood by us. If we are sufficiently educated, we (7) perceive and, while perceiving, distinguish forms of the word arbitrarily established at this stage of culture that are in the narrow sense morphological (morphemes), syntactic (syntagmas) and etymological (or rather, word form- 
ative). Of special note is the point of (8) distinguishing the emotional tone used by $N$ to accompany the transfer of the meaningful content of a message that we understand. The last issue is both a cultural and social fact and a natural one, on which the human (and animal) communication is based. Shpet specifically warns that this sequence does not reproduce the temporal empirical series in development and deepening of perception. In conclusion, he says: "The given above dismemberment of the word perception only approximately describes the most general outlines of its structure. Each member of it is a complex web of acts of consciousness" (Shpet, 1989, pp. 384-387). Levels of perception and understanding of the word classified by G.G. Shpet could be related to the division of mental functions on the natural and cultural, which was later suggested by L.S. Vygotsky, but for Shpet's warning that the sequence planned by him did not reproduce the temporary empirical series in the development and deepening of perception.

Identifying levels of a psychological act is only the beginning of the study of its structure. I shall not follow Shpet further who considers new givens, new functions, new deepenings and "steps" of perception and understanding when discussing the structure of the word, its external and internal forms. N.I. Zhinkin, a student and an employee of Shpet, wrote about holistic perception of the word structure: "The most diverse syllabic confluences within the syllabic flow are no hindrance. On the contrary, they tie the syllabic flow into a well-recognizable entity that has its own value. They are recognized as a whole like any objects. We do not need to take a good look and 'identify' a friend's eyes, nose, ears and other components of his face to recognize him" (Zhinkin, 1982, p. 17). The word has its own face that merges with its sense and meaning. Another thing is the way to such a perception of the word. (The opposite is also true: as Emmanuel Levinas put it, "The human face is a word.”)

There is a tiered organization present in the structure of activity proposed by A.N. Leontiev. Thus, the idea of processing the material (which the person encounters) at different levels is quite natural for psychology. The question is if there is that depth, into which one should (and would want to) immerse.

By way of illustration I will cite an extract from the art historical work of the Russian philosopher M.O. Gershenson: "The fascination of art is that smooth shiny iridescent ice crust, which comes from cooling the fiery lava of an artistic soul in contact with the outside air and with the truth... But at the same time the shiny icy crust hides depth from people making it inaccessible; this is a wise trick of nature. Beauty is a bait but beauty is also a barrier... It is opaque to the weak eye that is destined to enjoy only it alone - and is this a small reward? Only an intense and sharp gaze penetrates it and sees the depths, and the sharper it is, the deeper they are. Nature protects its small children like puppies with beneficent blindness. Art gives sustenance to each according to his strength: to one all the truth is given because he is mature enough; to another - only part of it; and to the third one only the truth's brightness is shown and the beauty of its form, so that the firing 
truth on entering the immature soul would not burn it to death and would not destroy its young tissues" (Gershenzon, 2001, pp. 228-229). In this passage we are talking about a possible depth of penetration into the internal shape of a work of art, and accordingly, and about the depth of understanding its meaning, about the completeness of the work's image constructed by the person perceiving it. Needless to say that the deeper understanding and aesthetic experience caused by a work of art, the stronger it will be maintained in the soul.

We are faced with a similar situation when perceiving, understanding and interpreting signs, words, symbols, myths and other mediators of artefacts. All of them have their own internal and external forms, the presence of which was articulated in antiquity, but the detailed elaboration of the concepts of internal and external forms of the word belongs to V.F. Humboldt, G. Shteynal, A.A. Potebnya and G.G. Shpet (see Bibikhin, 2007; Brandist, 2006; Van der Veer, 1996; Zinchenko V., 2000, 2007a). In light of their studies that were neglected by psychology during many years we are dealing not with the usual opposition between the uncertain external and internal, but with external and internal forms of the whole, which is a "meta-form." The external form of artefacts is relatively simple but their internal form is redundant and allows a large number of degrees of freedom when interpreting the whole. A.L. Dobrokhotov called this redundancy a "surplus value": "Regardless of the intentions of either the creator or the user any artifact secretly contains not only a utilitarian solution to a problem but also an instant of interpreting the world. This instant is the "surplus value" of an artifact that allows us to conceive culture as a whole and to move on to comparing its different phenomena, thus creating the general morphology of culture" (Dobrokhotov, 2008 , p. 12). The redundancy of the sign is, of course, minimal (but it exists!), while it is enormous in the symbol. Being memorized the artifact, due to its interpretative properties, intellectualizes memory. The penetration into the inner form of an artifact means familiarizing with culture. Images, generalizations, concepts that we create have the property of openness and are only limited by our own activity aimed at the world, nature and culture, at other people and ourselves. If we take into account the cumulative experience of humankind, we can confirm that understanding has no limits. Another argument in favour of this position belongs to Virgil who said that man tires of everything except understanding. This is what we know from our own experience. Accordingly, we should have used the experience of science to see the futility of search for "definitive" explanations and "final" truths. They are successfully replaced by the "inward surplus of space" created by us.

B.G. Meshcheryakov rightly correlated the idea of depth or levels of processing by Craik and Lockhart (Craik \& Lockhart, 1972) to the idea of activity and the mediation by activity (P.I. Zinchenko). But having said A one is to say B. The depth of activity levels should correspond to the depth of processing levels. And here studies by N.A. Bernstein devoted to the analysis of levels of construction of movement (Bernstein, 1947, 1966) and the 
research by A.V. Zaporozhets on the development of arbitrary movement (Zaporozhets, 1960) provided an invaluable favour to psychology. Bernstein traced the development of living motion from the background level $A$ (paleokinetic regulations) to the subcortical level $B$ (synergy and fixed patterns) and further to the cortical level $C$ of constructing the spatial field, and on to the next cortical level $D$ of subject action. Finally, he pointed to the last level $E$ that is located above the action level and goes beyond it. $\mathrm{He}$ called it the highest level of symbolic coordinations. Despite the fact that Bernstein linked levels of movement building with various levels of brain organization of behaviour, he followed A.A. Ukhtomsky and studied movement itself and action as "functional organs" of the individual that, like a living creature, evolve, involute and have reactivity and sensitivity. According to Ukhtomsky such functional organs as human conditions, images of the world, memories, etc. comprise any temporary combination of forces that are capable of realizing a certain achievement. They exist in a virtual reality and actualize in accordance with tasks of behaviour and activity. A functional organ reflects not something inherent to the individual and environment taken separately but what occurs in them as the result of their interaction and disappears when this interaction ceases. On being formed functional organs exist in a virtual reality as a set of means and techniques of activity (cognitive, affective, communicative, executive, etc.). The capacity to foresee is their most important feature. Contingently such organs can be referred to as the individual's cultural or activity potential, a kind of "music library" (N.A. Bernstein). L.S. Vygotsky preferred to use the terms "psychological tools" and "neoplasm" to describe mental acts. The idea of functional organs is not new. At the time J.G. Fichte said that man created organs assigned by soul and consciousness. Such acquisitions (creations) are more grounded than a building (Joseph Brodsky), and virtual reality far too often becomes more real than the real one.

While Bernstein discussed the "music library," we can speak about the "arsenal" of functional organs formed by man. It is important that Ukhtomsky came up with the idea of the individual's functional organs when he was pondering on the nature of the anatomy and physiology of the human spirit. This idea is close to the idea of personal constructs by J. Kelly (1963), which arose in the context of thinking about personality. It is advisable to distinguish relatively constant functional organs and operational ones. Among constant organs there are, for example, the integral image of the world, the word, cultural memory, intellectual methods and schemes, schemas of consciousness, motor skills, and so on. They have their own external and internal forms and are as redundant as artifacts (see above). The term "functional structure of cognitive and executive acts" is more suitable for such functional organs. Operational functional organs are those in action such as current dominants, the functional status of the individual, immediate cognitive and behavioural acts that are taking shape here and now. Kelly also emphasized that personal constructs are not just products but instruments of experience. In these, as in functional organs, 
there is not only Istwert, but Sollwert too.

According to Bernstein, levels determine the rank order of complexity and importance of the organism's actions in general. The external picture (form) of spatial actions is so complex that the metrics is not enough to describe it, and the use of topological categories is required. The involvement of various levels of movement in behaviour determines the image fullness of the surrounding environment. Poincare said that a still being could not build geometry.

Cognitive systems that regulate behaviour have no less complex structure than movement. For example, in studies of actual genesis (microgenesis) of perception a rank order of the percept complexity was obtained that was similar to action. U. Undeutsch, a student of F. Sander's (Undeutsch, 1942), identified the following stages of microgenesis: 1) the stage of a diffuse whole; 2) the stage of differentiation of figure and background, but yet without a clear perception of form; 3) the stage at which the observer begins to formulate working hypotheses regarding forms of identification (preconfiguraion stage); 4) the stage of a clear perception of the form. Different authors specify from three to six stages. Another controversy concerns the place that such perceptual categories as movement and colour take among stages of identification. There is a different logic of studying levels (or stages) of forming the image of form. According to it the identification (the differentiation of a figure from the background) should be followed by locating informative features (such as the contour shape) that are relevant to the task. Next the feature identified is introduced. The result is a generated image in which other features are involuntarily fixed that are irrelevant to tasks of introduction. When identifying a familiar object presented for a short time all these stages (similar to the stage of microgenesis) are obviously not present in the mind, and that gives an impression (an impression only?) of simultaneity, or one-actness, of identification.

There occurs an uneasy task of clarifying these stages or constructing possible hypotheses for mechanisms of simultaneous perception and recognition. For many years there has been a discussion of what kind of work flows on to acts of recognition and whether operations on individual features are performed in series or in parallel (Zinchenko T., 2000, 2002; Shekhter, 1967). An alternative approach is that as a result of learning sensory and perceptual standards (A.V. Zaporozhets, T.P. Zinchenko), operational units of perception (V.P. Zinchenko), memory operational units (P.I. Zinchenko, G.V. Repkina) are formed. These formations when at operation act as holistic, integrated facilities, or Gestalts. They are like quarks in which various elementary particles are merged. The term "sensory cohesion" by Berstein can be applied to them. Such parameters as stages of formation and its mediation through perceptual and mnemic actions are in a way removed or overcome in simultaneous acts of identifying operational units of perception and memory. They are perceived not only as one act, but also directly, which makes a basis for sensuous intuition, or "sense of meaning."

In my opinion, an interesting challenge is presented by investigating a 
possible ratio of the complexity of movement ranks, and those of the complexity of percept, and the way to the latter. There is another logic traced in the development of studies of information processing levels in short-term visual memory. They were mainly focused not on the content determined by the percipient, but rather on conservative and dynamic functional blocks ("boxes in the head") involved in the processing of information. Depending on the nature of tasks solved the process can involve sensory register, iconic memory, scanning, identification, formation of motor instructions (programs for use of the data obtained), operating, manipulation (mental rotation) of images, then programs of their actualization: a semantic processing unit (the retrieval and attribution of sense), repeating in the inner voice and, finally, a verbal or motor response. Each of the functional units is characterized by different ratios of conservative and dynamic properties. For example, conservative properties predominate in the sensory register, dynamic properties prevails in the semantic processing unit. In the latter case, the person penetrates into deeper layers of meanings and values (Zinchenko V., 1971). The maximum depth of processing is reached beyond short-term memory after acts of discourse when working with values and meanings.

Functional blocks (also known as levels) of processing information, similar to functional organs, exist in a virtual reality and are revealed as needed in the event of behavioural or other tasks. They may be organized hierarchically. Heterarchy is also possible and that can be a kind of cognitive pool, i.e. not consistent but a parallel combination of forces aimed at solving the problem. Identifying a large part of the listed and not listed above functional units discovered during almost half a century of the existence of cognitive psychology required inventing sophisticated experimental methods of investigation that are referred to as microstructural analysis and microdynamic analysis. All of them are carried out in a time range that is not available to any introspection and cannot be described in the "language of the internal." Unfortunately, it is only hypothetically possible to project the work of studied information processing levels in the short-term memory onto the real process of solving problems. Any decision is preceded by a phase of studying a problematic situation or a phase of information retrieval. Eye movements registration shows that at this phase there is a different duration of visual fixations. At each step of familiarizing with the situation the depth of processing and, accordingly, penetration into the situation are different (Ibid.). Such a hypothesis is not in contradiction with the possibility of a practically instantaneous grasp of the meaning of a situation. An example would be an experiment by V.B. Malkin that involved a chess grandmaster. The subject was given a task of memorizing a complicated chess position that was presented to him for a second. After the presentation the grandmaster said he did not remember what and where the figures were, but firmly stated that the Whites' position was weaker. This was indeed the case. The chess player was not to assess the position, the assessment was involuntary. In that case the semantic processing unit as if had moved forward and occupied the first place. This is not possible for an ordi- 
nary chess player who thinks in elements (individual figures), not situations (positions). What forms later in development, stands out in operation. A shift in places of levels and in stages of their formation and functioning resembles an Oriental proverb: when a caravan turns around the lame camel becomes the first. The semantic assessment level of the position that was formed last is the first to function.

The given above list of potential levels of information processing that are defined by tasks of attention, observation, memory and action is certainly not complete. If one is allowed to fantasize a little, it is possible to carry out an external analogy between the rank complexity of motor, perceptual and mental actions and ranks of reflexive penetration into the depth of the opponent's intentions. The latter corresponds to the content of reflexive games developed by V.A. Lefebvre.

Another focus was made in studies by A.V. Zaporozhets. When analyzing development of arbitrary movements (in Bernstein's terminology these are the levels $D$ and $E$ ) he focused on macrogenesis, i.e. on the deployment of the process of forming the image of a situation and the image of the course of action, which were to be performed in this situation. Zaporozhets referred to the situation image and the action image as to an internal picture (internal form) of arbitrary movements and actions, without which it is impossible to implement them efficiently. Consequently, the depth of processing depends not only on the perceived, or memorized, object, but also on the level of activity. Here we talk about synergy (in a different sense than that of the level $B$ by Bernstein) of image and action. More specifically, the action that leads to the image formation is an inner form of the existing image. In turn, the emerging or already established image becomes an internal form of movements and actions performed.

Such dynamic relationships between image and action are far from stimulus-reaction schemes used to describe behaviour. The image does not just cause an action but is transformed into action and becomes a way of control. However, it loses properties of redundancy and constancy necessary for making a decision either to act or to withdraw. The image of action possesses relevant to the task and quite real properties of the situation and of the object of the action. Decomposition of image and composition of action occur. The latter can be regarded, too, as decomposition of action, but action does not disappear altogether leaving behind not only the result, but also an image of the situation changed by the action.

We encounter amazing transformations of the image. The image of the present situation is transformed into the image of the required situation. In the terminology of N.A. Bernstein, this is a transformation of Istwert into Sollwert, and in terms of L.S. Vygotsky - into the relevant future field. The image of the required situation, in turn, is transformed into the image of action. Finally, when action begins, the image of action becomes an image in action and is embodied (rather than settles) in it. Everything that happens results in not only action in all its complexity becoming a subject action, but also in movement (through which the action is fulfilled), as if absorbing the subject, acquiring a subject outline. The great 
Charles Sherrington once talked about subject receptors. He was referring to vision and hearing. Both kinesthetics and proprioception become of a subject nature. Sensitivity of movement to itself, to its own flow is complemented by sensitivity to the situation and to the subject of the action. Moreover, the movement becomes sensitive to the meaning of a motor task, i.e. to the planned future results and the designed program of achieving it. And all this, as in the case of levels of processing in the visual short-term memory, occurs in the time range beyond introspection. But it happens not automatically (I wouldn't like to use the term "unconscious" here). The study by N.D. Gordeeva demonstrated that sensitivity of movement to itself and its sensitivity to the situation change in phase. Their alternation depends on the speed of movement: when performing, for example, a comfortable movement lasting about one second the sensitivity change observed happens with the interval from 100 to $200 \mathrm{~ms}$. In other words, there is a comparison of indications of both types of sensitivity and a correlation of the assessment obtained with the meaning of the current motor task. The observed effect was called the effect of background reflection. The latter even in simple movements occurs several times per second. It is important to note that with the shift of both types of sensitivity it does not fall to zero. Hence, it is possible to increase it in case of external or internal need (Gordeeva, 2007; Gordeeva \& Zinchenko V., 2001).

The presence of such a mechanism in due time was predicted N.A. Bernstein. After the person learning a skill identifies its motor structure and estab- lishes what the required movement will look like (from the outside), "he starts to understand what both the movement and sensory corrections managing it will feel like (from the inside)" (Bernstein, 1997, p. 238). This is nothing but looking inside oneself, of which we, even when performing complex actions, are not aware.

Consequently already at such deep levels of activity we observe its intentionality, reflexive nature, substantive complexity, etc. that allows us to speak not only of the unconscious but of the existential layer or the level of consciousness operation. This is true for macrogenesis of perception (or formation of a new image); for microgenesis of perception (or identification of a familiar image); for varying in complexity information transformations in short-term memory needed to solve problems or transfer it to long-term memory; for building movement and action (involuntary and arbitrary, forced and spontaneous, free). On the existential level of consciousness usual distinctions of the subjective and objective, the external and internal lose their sense. Of course, levels of processing information that have been studied or are being studied are subjective, but only in the sense that they belong to the individual. But this subjective quality is no less objective than the socalled objective quality. We are talking about special ontology of a single continuum of consciousness (the work of reflective and spiritual levels of consciousness requires special presentation (see Zinchenko V., 2006)).

I started this conversation about information processing levels and activity levels with the example relating to the psychology of art. It is known 
that perception of art plays an important role in the personal development of the individual. When immersing into internal forms of works of art we in fact immerse into ourselves and begin to build our own internal form, which is also not uniform and has its stages and levels. This, of course, applies not only to perception of art but has a broader meaning. But that is another story.

It is hardly necessary to explain that what was said about the image and action is directly related to memory and results of its studies by P.I. Zinchenko, Craik and Lockhart, as well as to the intended prospects of studying levels of its activity and the depth of processing. Their study not only are in no contradiction to each other, but they provide new grounds for interpreting human memory as a whole and its individual types (memorizing, saving, remembering, reproducing and forgetting) as a dynamic functional organ that undoubtedly possesses conservative properties too. Vladimir Nabokov suggested a vivid description of this functional organ: memory "evolves into an extraordinarily complex organ, which functions continuously, and its secretion compensates for all that has been lost; or else it becomes a fatal tumor on the soul that makes it painful to breathe, sleep, and associate with carefree foreigners." (In the latter case it refers to nostalgia of an emigrant.)

\section{Some prospects: from levels to functional organs and their models}

I will allow myself to make a general conclusion concerning levels of the depth of processing and levels of activity, regardless of whether the levels studied are related to perception, mem- ory, understanding, problem-solving or organizing action. Of course, the cognitive and executive acts investigated cannot contain the full measurements of aspects of the inner world or inner space of man. In my opinion, today the task for researchers is not only to increase the number of measurements but rather to establish meaningful connections between the already known approaches, each of which offers its own explanation of, in fact, one and the same subject studied from different angles. Although they are all different, but none of them pushes us towards reducing neurophysiological mechanisms that withdraws the explanation beyond psychology. V.N. Porus offers another way (instead of moving along the "reductionist slalom track") - that of constructing a topological system in which "levels," or "types," of explanations act as mutual "transcriptions," or means of reading their meanings in other languages (Porus, 2008, pp. 9596). This approach to understanding the whole has been overdue for quite a while, and to implement it there are already sufficient preconditions. As noted above, original ideas of cognitive and executive acts having a hierarchical organization turn out to be unsatisfactory and give way to ideas about their heterarchical organization. But when it comes to coordinating complex cognitive acts aimed at providing executive acts that have, in turn, a tiered structure, the situation becomes even more complicated. Heterarchy is not enough. Coordination is needed not only vertically between levels that are inside of a particular act. There should also be coordination along horizontals and diagonals, i.e. between levels belonging to different functional pat- 
terns of cognitive or executive acts. A. Koestler meant something similar when introducing the terms "matrix" and "bisociation" (M.K. Petrov preferred the term "multisociation" to the latter (Petrov, 2006, p. 33)). It can refer to a multiply-connected network of horizontal and vertical levels similar to a multiply-connected network of neurons linked by a principle of "each one with each one" (for more details see Bernstein, 1947; Zinchenko V. \& Nazarov, 1997). Such a "spatial" multiplyconnected network serves as a basis for the construction of functional models or structures of activity, which include components related to different levels. Experience of construing inter-level models has been gradually accumulated. It was started in motion control models proposed by N.A. Bernstein and his followers (Gordeeva, 1995). I will not go into the issue of how neurons "recognize" each other in multiply-connected networks. It is more important to answer the question of how levels or components related to different functional structures of cognitive and executive acts "recognize" each other. Considering such acts (constant functional organs) as metaforms helps to answer this question. Let me illustrate this with an example of action, word and image. The internal form of action includes the image and the word; the internal form of the image includes the action and the word; finally, the internal form of word includes the image and action. Metaforms, be they word, image or action, contain corresponding functional, verbal, perceptual, subject and operational values. They are not static but dynamic, and their dynamics generates meanings. V.Humboldt saw a forming idea of spirit as an internal form behind language forms. This idea is also present behind metaforms of image and action. All metaforms are certainly not impartial. There are feelings behind them. Thus, we have a weave, a fringe or garlands of internal forms where their constituent components are entangled by networks of direct and reverse connections (Zinchenko V., 2007a, 2008a). In such an analysis functional structures of action, image and word are more than "familiar." They are formations heterogeneous not only in their origin but also in their functioning, and it forms the basis of their relationships and interactions when addressing new challenges that arise in uncertain and changing conditions of behaviour and activity. Structures previously stored undergo decomposition while new structures required by tasks of activity go through the stage of composition (the latter include structures by means of which the future is to be constructed).

Likening (a mutual "transcription") of constant functional organs, functional structures of cognitive and executive acts to metaforms of action, word and image has fairly profound grounds. M.K. Mamardashvili considered form as an internal element of understanding, as "life organ" that compensates (or corrects) failure or uncertainty of life itself: "As events in the world acquire final identification in their "life organs," this is why they are not available for observation from outside: in case the external observer does not have the same organ" (Mamardashvili, 1997, p. 318). Speaking of forms Mamardashvili meant not statutory forms but forms of power, i.e. forms of certain tension that cannot be either physically or visually presented. 
Rhythm or dynamic pulsation are the form of which he speaks: "Form is the resonant container or box that it creates. Marcel Proust mentions somewhere the expression "resonance box" ("caisse de résonances") which is very imaginative and relevant to what I called the way... The ability to conform to such a form is indeed the voice of the point in us where freedom and necessity intersect" (Mamardashvili, 2000, p. 358). G.G. Shpet also described the internal form as a path. A.A. Ukhtomsky's assessment of the functional organ as "active rest" is close to it. Further, Mamardashvili (as if following Ukhtomsky's logic) talks about feeling, or sensitive, form that is different from our physical senses (Ibid., p. 319). And this form is not just a desire or fleeting impression, it is able to hold, maintain and translate itself: "The form, or structure, is the basis of the human condition having the property of infinity and understanding the infinite" (Mamardashvili, 1995, p. 266).

The infinite being both time and space. We mentioned earlier that functional organs exist in a virtual reality, that they are in a specific space and time - in the active chronotope. This is a different time that moves forward or backward or stops altogether, and a different space with polisensor rather than Cartesian or any other abstract coordinates. Once arisen, a functional organ continues to live in space and time of the chronotope, maintaining the connection with the outside world through subsystems of perception and movement configured by the organ. As a structure, or form, it is similar to dissipative structures capable of internal differentiation and self-organization (see Prigogine \& Stengers, 1997).
I had to appeal to works by Mamardashvili and Prigozhin, so that the reader would not have the impression of something elementary happening: functional organs, structures and metaforms were formed and then their elements scattered and self-organized (through environment) into new structures, and thus effective (intelligent, creative) behaviour and activity were ensured. These processes are far from being automatic; rather, they are dramatic where there is no happy ending guaranteed. To dispel the illusion of simplicity, I shall remind that G.G. Shpet had to write a monographic description to characterize the internal form of word $(1927 / 2005)$. The same description was undertaken by N.D. Gordeeva to characterize the functional structure of action (Gordeeva, 1995). The dynamics of the internal shape of image was also studied by V.P. Zinchenko, N.Yu. Vergilis (1969) and B.I. Bespalov (1984).

Without going into the dynamics of internal forms, I shall confine myself to a metaphorical characteristic of how man is opposed to uncertainty and variability of the world (of the external and internal world, if such a distinction still makes sense). I shall start with the meaning. M. Weber likened man to animal, which exists in the web of meanings that he wove himself (apparently from his own being). It is rather difficult to find a required knot in the web without making it vibrate. Movement is involved in overcoming critical situations. N.A. Bernstein likened living motion to a web in the wind; A.V. Zaporozhets compared living motion released from fixed patterns to the Aeolian harp. Living motion is involved in generating the image. Living image, in turn, can be vibrant, intense, painful 
and unsteady, i.e. as mobile as meaning and movement are. It is susceptible to operating, manipulation and transformation. It can be likened to the same web in the wind. The word is polysemantic and polysemic. It has to be found too: I lost the word that wanted you to hear,/And will the fleshless thought return to the hall of shadowes (Mandelstam). On the same subject: What agony! To search for a lost word. A similar way is used to describe behaviour of thought: "A thought's logic is like a wind blowing us on, a series of gusts and jolts. You think you've got to port, but then find yourself thrown back out onto the open sea, as Leibniz put it" (Deleuze, 1995, p. 94). Finally, readers anxious to find physiological mechanisms of behavioural and mental acts should be reminded that the closest metaphor was used by neuroscientists who claimed that the dendritic network of a living organism moves like tree branches do with a light breeze. These examples suggest that psychology must not only become more tolerant of uncertainty (Zinchenko V., 2007b), but also concentrate on ways of overcoming it.

Now let us remember that behind all the above mentioned acts there are complex functional structures that are in a non-equilibrium state and are just as necessary for the organization of behaviour and activity, as they are redundant. Operational functional organs are to be built of these elements (levels). Apparently, to describe this work it is really necessary to attract topological categories or (as N.A. Bernstein warned long ago) to build a new mathematics, which still does not exist and perhaps will hardly be constructed in the foreseeable future. We have to use poetic formulas and (relying on our own forces) build understandable or intelligible conceptual schemes.

Concluding the conversation about levels of the processing depth and levels of activity I have to confess that I cannot help feeling the mystery or miracle happening in human perception, memory, thinking. In the language of science this miracle is comprised in the move from successivity to simultaneity of perceiving the world. The same miracle is an amazing willingness of our memory that almost instantly selects what is needed at the moment from its scope that has any distinct boundaries. In the language of poetry it was expressed by William Blake: To see <...> Eternity in an hour... and by Boris Pasternak: This moment lasted an instant,/But it would eclipse eternity. Perhaps addressing the issue of how direct and indirect aspects in human cognition and activity are related to each other, could facilitate the approach to the mystery of simultaneity. In the end, the direct and indirect aspects are also levels of human mental life organization, of consciousness and activity. The author examines the thought in another paper (Zinchenko V., 2009) which is a continuation of this discussion.

All this, of course, can be called a fantasy. But psychology should one day become an objective science of the subjective world of man, and not only learn (and teach) how the individual finds his or her way in the external world. The first was a dream of the bright representative of the Kharkov Psychological School and later of the Moscow Psychological School, P.Ya. Galperin; the second was his real work. In my opinion, the study of involuntary memory in a broad sense (including memorizing, remembering and forgetting), which 
began with works by P.I.Zinchenko and is the subject of our discussion, is closer to making the dream of his friend P.Ya. Galperin come true.

\section{References}

Asmus, V. F. (1984). Istoriko-filosofskie etyudy [Historical philosophical studies]. Moscow: Mysl'.

Bartlett, F. (1932). Remembering. A study in experimental and social psychology. Cambridge: Cambridge University Press.

Bernstein, N. A. (1947). O postroenii dvizhenii [On the construction of movement]. Moscow: Medgiz.

Bernstein, N. A. (1966). Ocherki po fiziologii dvizheniya i fiziologii aktivnosti [Essays on physiology of activity]. Moscow: Meditsina.

Bernstein, N. A. (1997). Biomekhanika i fiziologiya dvizhenii [Biomechanics and the physiology of movement]. Moscow/Voronezh.

Bespalov, B. I. (1984). Deistvie. Psikhologicheskie mekhanizmy vizual'nogo myshleniya [Action. The psychological mechanisms of visual thinking]. Moscow: Moscow University Press.

Bibikhin, V. V. (2007). Mir [The world] (2nd ed.). Saint Petersburg: Nauka.

Bibikhin, V. V. (2008). Vnutrennyaya forma slova [The inner form of word]. Saint Petersburg: Nauka.

Brandist, C. (2006). The rise of Soviet sociolinguistics from the ashes of Vцlkerpsychologie. Journal of the History of the Behavioral Sciences, 42(3), 261-277.

Brodsky, J. (2001). Poklonit'sya teni [To please a shadow]. Saint Petersburg: Azbuka-klassika.

Cermak, L., \& Craik, F. (Eds.) (1979). Levels of processing and human memory. Hillsdale, NJ: Erlbaum.

Cole, M. (1980). Introduction: The Kharkov school of developmental psychology. Soviet Psychology, $18(2)$.

Cole, M. (1996). Cultural psychology: A once and future discipline. Cambridge, MA: Belknap Press of Harvard University Press.

Craik, F., \& Lockhart, R. (1972). Levels of processing: A framework for memory research. Journal of Verbal Learning and Verbal Behavior, 11(6), 671-684.

Deleuze, G. (1995). Negotiations. New York: Columbia University Press.

Dobrokhotov, A. L. (2008). Kruglyi stol: Kul'turologiya kak nauka: za i protiv [The round table: Culturology as a science: pro et contra]. Voprosy Filosofii, 11.

Gershenzon, M. O. (2001). Gol'fstrem. Klyuch very. Mudrost' Pushkina [Gulf Stream. The key to faith. Pushkin's wisdom]. Moscow: Agraf.

Gordeeva, N. D. (1995). Eksperimental'naya psikhologiya ispolnitel'nogo deistviya [Experimental psychology of executive action]. Moscow: Trivola.

Gordeeva, N. D. (2007). Productive chaos as a condition for a perfect action. Voprosy Psikhologii, 3, 116-127. (in Russian)

Gordeeva, N. D., \& Zinchenko, V. P. (2001). Rol' refleksii v postroenii predmetnogo deistviya [The role of reflection in the construction of subject's action]. Chelovek, 6, 26-41.

Kandinsky, V. (2004). Tochka i liniya na ploskosti [Point and line to plane]. Saint Petersburg: Azbukaklassika.

Kelly, G. A. (1963). The psychology of personal constructs. London: Routledge.

Leontiev, A. N. (1967). Bor'ba za problemu soznaniya v stanovlenii sovetskoi psikhologii [The fight for the problem of consciousness in the making of the Soviet psychology]. Voprosy Psikhologii, 2. 
Leontiev, A. N. (1931). Razvitie pamyati [The development of memory]. Moscow: Uchpedgiz.

Leontiev, A. N. (1983). Izbrannye psikhologicheskie proizvedeniya [Selected psychological writings] (in 2 Vols). Moscow: Pedagogika.

Luria, A. R. (1968). Malen'kaya knizhka o bol'shoi pamyati [A little book about a vast memory]. Moscow: Moscow University Press.

Luria, A. R. (2002). Priroda chelovecheskikh konfliktov [The nature of human conflicts]. Moscow: Kogito-Tsentr.

Mamardashvili, M. K. (1995). Lektsii o Pruste [The lections on Proust]. Moscow: Ad Marginem.

Mamardashvili, M. K. (1997). Psikhologicheskaya topologiya puti [The psychological topology of the way]. Saint Petersburg: Zhurnal "Neva".

Mamardashvili, M. K. (2000). Estetika myshleniya [Aesthetics of thinking]. Moscow: Moskovskaya shkola politicheskikh issledovanii, 2000.

Meshcheryakov, B. G. (2004). Pamyat' cheloveka: effekty i fenomeny [The human memory: effects and phenomena]. Moscow: Voprosy Psikhologii.

Meyerhold, V. (1968). Stat’i. Rechi. Pisma. Besedy [Papers. Speeches. Letters. Discussions] (in 2 Vols.). Moscow: Iskusstvo.

Petrov, M. K. (2006). Filosofskie problemy "Nauki o nauke". Predmet sotsiologii nauki [The philosophical problems of the "science of science". The subject of the sociology of science. Moscow: ROSSPEN.

Porus, V. N. (2008). Kak ob"yasnit'? Znak razvilki na puti psikhologii [How to explain? The junction sign on the way of psychology]. Methodology and History of Psychology, 3(1), 88-97.

Prigogine, I., \& Stengers, I. (1997). The end of certainty: Time, chaos, and the new lawes of nature. New York/London/Toronto/Sydney/Singapore: The Free Press.

Rubinstein, S. L. (1973). Chelovek i mir [Man and world]. In S. L. Rubinstein, Problemy obshchei psikhologii [Problems of general psychology]. Moscow: Pedagogika.

Shekhter, M. S. (1967). Psikhologicheskie problemy uznavaniya [Psychological problems of recognition]. Moscow: Prosveshchenie.

Shpet, G. (1989). Sochineniya [Writings]. Moscow: Pravda.

Undeutsch, U. (1942). Die Aktualgenese in ihrer Allgemein Philosophischen und ihrer characterologischen Bedeutung. Scientia, 72, 37.

Valsiner, J. (1988). Developmental psychology in the Soviet Union. Brighton, Sussex: Harvester Press.

Van der Veer, R. (1996). The concept of culture in Vygotsky's thinking. Culture and Psychology, 2(3), $247-263$.

Vasilyuk, F. G. (2007). Ponimayushchaya psikhoterapiya: opyt postroeniya psikhotekhnicheskoi sistemy [The understanding psychotherapy: the experience of construal of a system of psychotechnics]. Vestnik Prakticheskoi Psikhologii v obrazovaniya, 3, 27-41.

Vdovina, I. S. (1999). Ot pervichnogo vospriyatiya k miru kul'tury [From the primal perception to the world of culture]. In M. Merleau-Ponty, Fenomenologiya vospriyatiya [Phenomenology of perception]. Saint Petersburg: Yuventa/Nauka.

Vygotsky, L. S. (1926). Pedagogicheskaya psikhologiya [The educational psychology]. Moscow.

Yasnitsky, A. (2008). History of Kharkov school of psychology documentary: period of 1931-1936. Kul'turno-istoricheskaya Psikhologiya [Cultural-Historical Psychology], 3, 92-102. (in Russian)

Yasnitsky, A., \& Ferrari, M. (2008a). Rethinking the early history of post-Vygotskian psychology: the case of the Kharkov school. History of Psychology, 11(2), 101-121. 
Yasnitsky, A., \& Ferrari, M. (2008b). From Vygotsky to Vygotskian psychology: Introduction to the history of the Kharkov school. Journal of the History of the Behavioral Sciences, 44(2), 119-145.

Yudin, E. G. (1978). Sistemnyi podkhod i printsip deyatel'nosti. Metodologicheskie problemy sovremennoi nauki [The system approach and the principle of activity: Methodological problems of contemporary science]. Moscow: Nauka.

Zaporozhets, A. V. (1960). Razvitie proizvol'nykh dvizhenii [Development of voluntary movements]. Moscow: Akademiya pedagogicheskikh nauk RSFSR.

Zhinkin, N. I. (1982). Rech' kak provodnik informatsii [Speech as a mediator of information]. Moscow: Nauka.

Zinchenko, A. V. (2001). Nostalgia and discontinuity of life: A multiple case study of older ex-Soviet refugees seeking psychotherapeutic help for immigration-related problems. Unpublished Ph.D. dissertation, Saybrook Graduate School.

Zinchenko, P. I. (1939a). Problema neproizvol'nogo zapominaniya [The issue of unintentional memorization]. Nauchnye Zapiski Khar'kovskogo Pedagogicheskogo Instituta Inostrannykh Yazykov, 1.

Zinchenko, P. I. (1939b). O zabyvanii i vosproizvedenii shkol'nykh znanii [On forgetting and remembering school knowledge]. Nauchnye Zapiski Khar'kovskogo Pedagogicheskogo Instituta Inostrannykh Yazykov, 1.

Zinchenko, P. I. (1961). Neproizvol'noe zapominanie [Unintentional memorizing]. Moscow: Akademiya pedagogicheskikh nauk RSFSR.

Zinchenko, T. P. (2000). Kognitivnaya i prikladnaya psikhologiya [The cognitive and applied psychology]. Moscow/Voronezh: MPSI/NPO "MODEK".

Zinchenko, T. P. (2002). Pamyat'v eksperimental'noi i kognitivnoi psikhologii [Memory in experimental and cognitive psychology]. Saint Petersburg: Piter.

Zinchenko, V. P. (1971). Produktivnoe vospriyatie [The productive perception]. Voprosy Psikhologii, 6.

Zinchenko, V. P. (2000). Mysl' i slovo Gustava Shpeta [The thought and the word of Gustav Shpet]. Moscow: Izdatel'stvo URAO.

Zinchenko, V. P. (2006). Soznanie kak predmet i delo psikhologii [Cognition as a subject and matter of psychology]. Methodology and History of Psychology, 1(1), 207-231.

Zinchenko, V. P. (2007a). Generation of meaning: Metaphor's assembling. Kulturno-istoricheskaya Psikhologiya [Cultural-Historical Psychology], 3, 17-32. (in Russian)

Zinchenko, V. P. (2007b). Tolerance towards vagueness: Is it news or a psychological tradition? Voprosy Psikhologii, 6, 3-22. (in Russian)

Zinchenko, V. P. (2008a). Geterogenez tvorcheskogo akta: slovo, obraz i deistvie v "kotle Cogito" [The heterogenesis of creative act: word, image and action in the "pot of Cogito"]. In V. A. Lektorskii (Ed.), Kognitivnyi podkhod: filosofiya, kognitivnaya nauka, kognitivnye distsipliny [Cognitive approach: philosophy, cognitive science, cognitive disciplines]. Moscow: "Kanon+" ROOI "Reabilitatsiya".

Zinchenko, V. P. (2008b). Early stages of cultural development of the child. Dubna Psychological Journal, 1(1). Retrieved from http://psyanima.su/journal/2008/1/2008n1a2/2008n1a2.pdf (in Russian)

Zinchenko, V. P. (2008c). "Perhaps the whisper was born before the lips..." What precedes the explosion of child language. Kul'turno-istoricheskaya psikhologiya [Cultural-Historical Psychology], 2, 2-18. (in Russian)

Zinchenko, V. P. (2009). Do we need to overcome the immediacy postulate? Voprosy Psikhologii, 2, 3-20. (in Russian) 
Zinchenko, V. P., \& Meshcheryakov, B. G. (2000). Sovokupnaya deyatel'nost' kak geneticheski iskhodnaya edinitsa psikhicheskogo razvitiya [Comprehensive activity as a genetically initial unit of psychic development]. Psikhologicheskaya Nauka i Obrazovanie, 2, 86-95.

Zinchenko, V. P., \& Nazarov, A. I. (1997). Posleslovie [Afterword]. In N. A. Bernshtein, Biomekhanika i fiziologiya dvizhenii [Biomechanics and the physiology of movement]. Moscow/Voronezh.

Zinchenko, V. P., \& Vergiles, N. Yu. (1969). Formirovanie zritel'nogo obraza [Formation of visual image]. Moscow: Moscow University Press.

Zinchenko, V. P. Thought and word: The approaches of L. S. Vygotsky and G. G. Shpet. In H. Daniels, M. Cole, \& J. V. Wertsch (Eds.), The Cambridge Companion to Vygotsky. Cambridge.

Работа печатается по изданию: Зинченко, В. П. (2009). Живая память в исследованиях П.И. Зинченко (ретроспект и проспект). Культурно-историческая психология, 3, 2-15.

Перевод и публикащия материалов производились с разрешения ЦГИ Принт. 